This item was submitted to Loughborough's Research Repository by the author.

Items in Figshare are protected by copyright, with all rights reserved, unless otherwise indicated.

\title{
International experience and FDI location choices of Chinese firms: The moderating effects of home country government support and host country institutions
}

\section{PLEASE CITE THE PUBLISHED VERSION}

https://doi.org/10.1057/jibs.2013.68

\section{PUBLISHER}

(C) 2014 Academy of International Business. Published by Springer

\section{VERSION}

AM (Accepted Manuscript)

\section{PUBLISHER STATEMENT}

This work is made available according to the conditions of the Creative Commons Attribution-NonCommercialNoDerivatives 4.0 International (CC BY-NC-ND 4.0) licence. Full details of this licence are available at: https://creativecommons.org/licenses/by-nc-nd/4.0/

\section{LICENCE}

CC BY-NC-ND 4.0

\section{REPOSITORY RECORD}

Lu, Jiangyong, Xiaohui Liu, Mike Wright, and Igor Filatotchev. 2019. "International Experience and FDI Location Choices of Chinese Firms: The Moderating Effects of Home Country Government Support and Host Country Institutions". figshare. https://hdl.handle.net/2134/28394. 
International experience and FDI location choices of Chinese firms:

The moderating effects of home country government support and host country institutions

\author{
Jiangyong Lu \\ Department of Strategic Management \\ Guanghua School of Management \\ Peking University \\ Beijing, China, 100871 \\ Tel: +86(0)1062757913 \\ Email: lujiangyong@gsm.pku.edu.cn
}

\author{
Xiaohui Liu \\ Business School \\ Loughborough University \\ Leicestershire LE11 3TU \\ Tel: + 44 (0)1509 223349 \\ e-mail: $\underline{\text { X.Liu2@lboro.ac.uk }}$
}

Mike Wright

Centre for Management Buy-out Research

Nottingham University Business School

Nottingham NG8 1BB, UK

Tel: +44 (0)115951 5257

And

EMLyon

Email: mike.wright@nottingham.ac.uk

\title{
Igor Filatotchev
}

Sir John Cass Business School

City University London

London EC1Y 8TZ, UK

Tel: +44(0)207040 5278

Email: igor.filatotchev@city.ac.uk 


\title{
International experience and FDI location choices of Chinese firms:
}

\section{The moderating effects of home country government support and host country institutions}

\begin{abstract}
We examine the extent to which Chinese government support of foreign direct investment (FDI) projects and host country institutional environments interact with prior entry experience by Chinese firms, and how this interrelationship affects FDI undertaken by Chinese firms. We hypothesize that home country government support and well-established host country institutions enhance organizational capabilities to take risks in FDI. As such, they reduce the need to accumulate experiential knowledge and capabilities relating to entering host countries based on prior entry experience in a particular country when undertaking follow-up investment projects. Using a unique, hand collected panel dataset of Chinese publicly listed firms during 2002-2009, we find that home government support and well developed host country institutions reduce the importance of prior entry experience and significantly increase the likelihood of FDI entry into a host country. Further, from our sub-sample analyses we identify differences between entering developed and developing host countries in terms of the impact of home country government support and quality of host country institutions. Our findings help explain the puzzle concerning why EE firms have rapidly internationalized in a short period of time and do not follow the pattern predicted by classical IB theories. In comparison with studies from developed country contexts, our findings also highlight that the effect of home country support may be context specific.
\end{abstract}




\section{INTRODUCTION}

We extend previous IB research by considering the contingency effects of both home country government FDI support policies and the host country environment on the knowledge and capabilities required for entry into foreign markets by emerging economy (EE) firms in the specific context of China. As latecomers, Chinese firms typically lack intangible resources, such as advanced technologies, marketing techniques, established brands, and they have limited knowledge about potential host countries, compared to Western counterparts. Yet, Chinese firms often take a large step in internationalization by investing in countries which differ institutionally from their home country and by seeking knowledge and institutional support to mitigate disadvantages of their late arrival (Mathews \& Zander, 2007). A growing body of research suggests that Chinese firms engage in foreign direct investment (FDI) due to multiple factors that include macro-business environmental forces as well as firm-level dynamics (e.g., Lu, Liu \& Wang; 2011; Wang, Hong, Kafouros \& Boateng, 2012). This calls for the exploration of multiple factors affecting internationalization by EE firms in general and Chinese firms in particular (Hitt, Beamish, Jackson \& Mathieu, 2007).

Early literature on FDI from developed countries largely focused on institutions in MNEs' host countries (Globerman \& Shapiro, 2003; Henisz \& Zelner, 2005). In contrast, FDI by firms in EEs, such as China, has attracted increasing research interest in the role of home country government support in facilitating internationalization (Cui \& Jiang, 2012; Luo \& Tung, 2007; Wang, Hong, Kafouros \& Wright, 2012). For EE firms with relatively little internationalization experience, home country government support may be critical for facilitating access to resources and enhancing EE 
firms' capabilities to take risks in foreign entries (Luo \& Tung, 2007). However, the extant IB literature seldom considers institutions in both host and home countries simultaneously (Holburn \& Zelner, 2010; McGahan \& Victer, 2010). In particular, the interrelationship between home country government strategy with regard to FDI by local firms, host country institutions and prior international experience of EE firms has been largely overlooked. We focus upon home country government support as a particularly distinctive aspect of the home country institutional context for Chinese firms. Considering the interplay between external factors and firms' international experience is especially important for Chinese firms, since home country government support and favorable host country institutions may help overcome constraints imposed by the lack of international experience of latecomers from China. In other words, the capability implications associated with home government support and well-established host country institutions may offset the need to accumulate experiential knowledge about host countries. Therefore, we address the following research question: How and to what extent do host and home country institutional factors moderate prior international experience in influencing foreign entries by Chinese firms into a specific country? Specifically, we examine whether home country government support and well-established host country institutions reduce the need for previous entry experience in a particular country when undertaking follow-up investment projects. To examine this research question we compile a longitudinal dataset drawn from publicly listed firms in China during the period of 2002-2009.

We make several contributions to the IB literature. First, we integrate the knowledge-based view (KBV) with the institutional context of the home and host countries by examining interrelationships between a host country's institutional environment, the home government's policies to promote FDI, 
and a firm's previous entry experience in a particular country. We show that home government support and well-developed host country institutions enhance organizational capabilities to take risk and moderate the need for previous entry experience in the host country by focal firms. This implies that the prior knowledge and capabilities required for a foreign entry may be institutionally embedded. Specifically, the extent to which prior international experience is important is contingent on the institutional context of both home and host countries. This represents an important extension of the $\mathrm{KBV}$ in the FDI context.

Second, we contribute to the identification of boundary conditions concerning the influence of institutional contexts for FDI by finding that, for Chinese firms, home country government support not only acts as a financial incentive as identified by recent studies (Buckley, Clegg, Cross \& Voss, 2010; Lu, et al., 2011), but also as an important contingency factor which compensates for EE firms' competitive disadvantages and organizational deficiencies in terms of foreign entries (Luo \& Tung, 2007). This is an important insight given the particular challenges faced by relatively less experienced Chinese firms in making FDI entries, and their close relationship with their home government. In comparison with studies from developed country contexts, our findings highlight that the effect of home country support may be context specific and help to explain the puzzle concerning why some EE firms have rapidly internationalized in a short period of time and do not follow the pattern predicted by classical IB theories. We go beyond the boundary of the KBV by examining the inter-relationship between firms' prior international experience and contextual forces, such as home country government support. 
Third, we extend recent conceptual and empirical developments that have focused on the home country institutional context in showing that EE firms have different motives and different investment patterns when they invest in developing countries and developed countries (Wang, Hong, Kafouros \& Wright, 2012). Specifically, we argue and show that these differences are driven by differential effects of home government FDI support policies and host country institutions depending upon whether entry is into developed or developing economies. Home government FDI support policies playing a stronger substitutive role with regard to prior experience when firms choose to enter developing countries, while the quality of host country institutions have a stronger substitution effect when firms choose to enter developed countries. This is an important finding suggesting that the moderating roles of macro institutions are far from universal but instead are contingent on the level of development of the host country.

\section{THEORY AND HYPOTHESIS DEVELOPMENT}

Knowledge is a multi-dimensional and context-based construct. It broadly consists of tacit and codified knowledge as well as organizational capabilities (Grant, 1996; Nonaka, 1994). Tacit knowledge is associated with skills, experience and contextual knowledge, whereas codified knowledge is less context-specific and can be articulated and relatively easily transferred across organizational and national boundaries (Kogut \& Zander, 1993; Szulanski, 1996). In addition to different types of knowledge, the KBV also highlights the importance of organizational capabilities which are a firm's ability to absorb, integrate and transform internal and external knowledge to create competitive advantages (Amit \& Schoemaker, 1993; Grant, 1996; Sirmon, Hitt \& Ireland, 2007). 
Organizational capabilities are not necessarily directly linked to a specific task but are related to the ability to cope with complex and uncertain environments in a host country ( $\mathrm{Lu}$, Zhou, Bruton \& $\mathrm{Li}$, 2010). Specifically, the KBV of internationalization emphasizes that knowledge about host countries informs foreign entry decisions, and organizational capabilities are vital in dealing with risks and uncertainties in foreign operations, as well as minimize the resource provisions necessary to buffer the adverse effects of "venturing into the unknown" (Kogut \& Zander, 1993; Kostova \& Zaheer, 1999; Martin \& Salomon, 2003).

While extant literature has emphasized that firms can obtain knowledge about host countries through experiential learning (Pedersen \& Shaver, 2011), the contingency effects of home country government support and host country institutions on experiential learning have been unexplored. This aspect is particularly relevant to firms in EEs. For example, although Chinese firms do not possess superior knowledge-based endowments compared with traditional MNEs from developed countries, appropriate institutional environments or well-established institutions in host countries and government support associated with FDI policies in the home country may enhance firm capabilities to take risks, thus compensating for the lack of international experience and knowledge about foreign markets and enable these firms to accelerate the internationalization process (Buckley, et al., 2010; Luo \& Tung, 2007).

There is, therefore, a need to integrate $\mathrm{KBV}$ into the institutional context to examine whether the interrelationship between institutional factors and prior international experience affects foreign entries by Chinese firms. This aspect has been largely neglected in existing studies which often examine 
either the importance of host country institutions or home country government support or firms' internationalization experience in isolation (Casillas \& Moreno-Menéndez, 2013; Eriksson, Johanson, Majkgard \& Sharma, 1997; Luo, Xue \& Han, 2010). Such a research setting largely limits our understanding of how firms interact with institutions in both home and host countries in making foreign entry decisions.

This study, therefore, moves beyond existing research by considering the interplay between the prior international experience of firms and the institutional context of both home and host countries. More specifically, we draw upon the KBV to develop hypotheses which take account of the contexts of the home country government's policies to promote FDI, a host country's institutions to attract FDI, and firms' prior entry experience. We examine how home government support and host country institutional contexts interact with the prior entry experience of the focal firm and examine whether institutional contexts enhance risk-taking capabilities, thus reducing the need for firms' prior entry experience. In other words, we consider home country government support and host country institutional contexts as important contingency factors and capability enhancing mechanisms that may affect the marginal benefits of experiential learning and subsequent decision to invest in a particular country (Luo \& Tung, 2007). This aspect has been under-explored in previous KBV-grounded models of FDI, given that prior research has predominantly focused on the relationships between the characteristics of knowledge (tacit or codified), transferability of knowledge and firms' competitive advantages across borders (Kogut \& Zander, 1993; Martin \& Salomon, 2003). Therefore, our theoretical and empirical analysis helps deepen understanding of how prior international experience and contextual factors jointly affect Chinese firms' location choices and provides new insights into 
how these forces affect the strategic behavior of Chinese firms in FDI.

\section{Firms' Prior Entry Experience and Home Country Government Support}

From the KBV, a firm's prior entry experience represents firm-specific knowledge that is difficult to imitate (Martin \& Salomon, 2003; Meyer, Wright \& Pruthi, 2009). Such experience allows firms to develop organizational capabilities and overcome obstacles to a foreign market entry. Organizational capabilities may be derived from managing economies of scale and scope resulting from repeated investment (Henisz \& Macher, 2004). Prior entry experience also helps firms gain knowledge about the host country and build a local knowledge base, and so overcome the liability of foreignness (Peng, 2001). This local knowledge base includes access to local knowledge through collaborations with local firms (Kogut \& Zander, 1993) and development of local distribution networks and access to local customers (Anand \& Delios, 1997). Hence, prior international experience with a host country and organizational capabilities associated with foreign operations may encourage firms to select the country for further new investments instead of choosing a new country.

In addition to a local knowledge base, firms' prior international experience helps reduce the risks involved in going abroad and influences managers' perceived costs of internationalization (Eriksson, et al., 1997; Johanson, \& Vahlne, 2009). Firms can utilize prior experience of a host country to further expand operations in that country to achieve scale economies in production and marketing. Subsequent entries into the same host country enable firms to deepen their understanding of a business context and improve their organizational capabilities to adapt to local conditions via experiential learning (Henisz \& Macher, 2004). 
However, these arguments assume firms gain crucial knowledge about host countries and develop organizational capabilities only through incremental and time-consuming learning-by-doing processes of conducting business abroad (Casillas \& Moreno-Menéndez, 2013; Pedersen \& Shaver, 2011). This assumption overly emphasizes path dependency and experiential learning, but overlooks the contingency impact of home government support on experiential learning in terms of foreign entry. In other words, this assumption which focuses on firms' experiential learning has largely ignored the role of home country factors in internationalization (Guler \& Guillen, 2010).

Many developed and developing countries have introduced FDI policies associated with national trade and development objectives that provide various benefits to firms that comply with these policies (Aharoni \& Ramamurti, 2008; Kumar, 2007; Shapiro \& Globerman, 2003). The Chinese government, for example, regularly issues guidelines that cover countries and industries in which the Chinese government supports investments by Chinese firms. Home country government support may have a dual moderating impact on the relationship between a firm's prior FDI experience and investment decisions. From the KBV, the home country government can facilitate domestic firms' internationalization by supplying knowledge about foreign countries which can be used by domestic firms when venturing abroad. Such knowledge may be contained in official guidance procedures based on, for example, knowledge of a particular country collected through diplomatic channels and intensive research carried out by government agencies. This is a "supply-side" effect of government support in terms of the required experiential knowledge associated with a specific entry decision.

More importantly, the home government's policy requirements and preferences can also affect 
investing firms' capabilities to take risk in the context of uncertainty and information asymmetries concerning foreign markets. Luo et al. (2010: 74) indicate that "companies complying with requirements have preferential treatment concerning funding, tax collection, foreign exchange, customs and others". These authors also state that: "...all investments complying with these guidelines enjoy favorable financial support, exchange rates, taxation, and other favorable treatment" (76). This resource "shield" may enable companies to buffer the risks and uncertainties associated with investing in a specific country/industry included in the state guidance. Since prior international experience is used to overcome these risks and uncertainties, state support may reduce its marginal benefits, other things being equal. Therefore, complying with state policy may help to enhance risk-taking capabilities and reduce the pressure on firms to rely on prior experience to deal with uncertainties in international operations, representing a "demand-side" effect on the importance of prior learning (Cui \& Jiang, 2012).

The above discussion implies that the knowledge and organizational capabilities required for a successful entry may be institutionally embedded, and home country government support may foster Chinese MNEs to springboard internationally without having accumulated much international experience (Luo \& Tung, 2007). When a firm complies with or actively utilizes home country government support, including financial and non-financial benefits, its risk-taking capabilities are heightened, thus reducing the necessity of prior international experience. As such, home country government support may offset the need (i.e., substitute) for a firm's prior entry experience: 
Hypothesis 1: A Chinese firm's compliance with government FDI support policy will reduce the importance of its prior international experience in a host country in facilitating an FDI entry.

\section{Firms' Prior Entry Experience and Host Country Institutions}

Previous research indicates that host country institutions affect MNEs' organizational capabilities to access external resources and take risk in a host country and, therefore, also affect MNEs' entry decisions (Guler \& Guillén, 2010). Host country institutions also affect knowledge access capabilities of firms, significantly shaping firms' market entry strategies (Meyer, et al., 2009). Institutional environments that support business development may be a magnet for foreign firms wanting to take advantage of favorable conditions (Uhlenbruck, Rodriguez, Doh \& Eden, 2006). Well-established market supporting institutions are able to provide support services to foreign firms and an efficient common infrastructure that reduce transactional uncertainty (McEvily \& Zaheer, 1999). They also help firms reduce search costs associated with accessing critical knowledge for foreign operations (Meyer, et al., 2009).

Despite the importance of host country institutions in facilitating FDI entry, previous studies consider prior international experience as crucial for FDI entry (Eriksson, et al., 1997; Johanson \& Vahlne, 2009). However, well-established market supporting institutions in a host country may provide institutional support necessary to attract foreign firms, and such an institutional context enables firms to gain sufficient knowledge about the institutional environment in that country. In other words, the importance of prior international experience in that particular host country may decline in relation to FDI entry when firms operate in a well-established and supportive institutional context. 
There are two main reasons for this relationship.

First, firms operating in foreign countries encounter unfamiliarity and discrimination costs associated with their foreign operations (Miller \& Eden, 2006). Such costs are expected to be low if a host country has a well-established institutional environment in which foreign firms can easily follow 'the rules of the game' and gain information necessary for their operations (Schwens \& Kabst, 2011). Such increased perceived institutional familiarity may reduce reliance on prior international experience.

Second, well-developed institutions may help foreign firms make links with customers, suppliers, and local business communities. Again, this increased perceived business familiarity encourages firms to make further expansion. A host country with a well-established institutional environment may have implemented a set of investment-supporting institutions, such as property rights regulations which constrain government expropriation of firms, and contracting institutions which protect firms from infringement by private businesses and facilitate market transactions (Acemoglu \& Johnson, 2005). Thus, we argue that well-developed institutions in host countries reduce the importance of experiential learning as firms face low political risks and uncertainty when operating in such a context. On the other hand, under-developed institutions generate hazards of expropriation and transactional uncertainty, and so foreign firms have to rely on their prior experience to understand, interpret and deal with political and operational risks in foreign locations. This implies that direct experience of a host country is no longer seen as a necessary condition for FDI entry when firms operate in a host country with well-established institutions. 
In summary, we posit that although a host country's institutions do not directly contribute to a firm's knowledge, well developed host country institutions help boost risk-taking capabilities by reducing information asymmetry and regulatory ambiguity associated with investment projects. Such an institutional context reduces the incremental benefits of experiential learning that is aimed at gaining knowledge about how to deal with risks and uncertainties in a specific country. The reduced institutional uncertainty may also be associated with a larger reliance on contractual means of dealing with risks as opposed to informal, cognitive mechanisms (He, Brouthers \& Filatotchev, 2013). These two aspects of a host country's institutional environment may significantly reduce the firm's reliance on prior international experience in this country. Hence, we hypothesize:

Hypothesis 2: High quality of host country institutions will reduce the importance of a Chinese firm's prior international experience in a host country in facilitating an FDI entry.

\section{Developed and Developing Country Contexts}

So far, we have not distinguished whether entry is into developed or developing countries yet their influence on entry decisions may be different. Recent studies revealed that EE firms have different motives and show different investment patterns when they invest in developing countries and developed countries. For example, Wang, et al. (2012) found that government affiliation levels of Chinese MNEs have a higher positive impact on these firms' investment into developed countries than into developing countries. EE firms' capabilities that are shaped by home country institutional context are highly relevant to under-developed institutions and may be more easily transferable to other developing economy contexts (Cuervo-Cazurra \& Genc, 2008, Luo \& Peng, 1999; Wright, Filatotchev, 
Hoskisson \& Peng, 2005). Home governmental support may play a larger role in supporting Chinese MNEs to invest in developing countries, where host country institutional environment conditions matter less in Chinese MNEs' FDI decisions since they have already built strong capabilities in operating in an institutionally stringent environments and there is therefore a lower knowledge gap. For example, the Chinese government has pushed Chinese MNEs to invest in gold mining in Ghana and has reportedly been able to exert pressure on the Ghanaian government to allow firms to bypass local regulations (UNCTAD, 2007). The underlying reason is that home government support helps reduce the uncertainty and operational risks associated with under-developed institutions in these countries and hence substitutes for the need to have prior experience in the host country (Luo, et al. 2010).

In contrast, EE firms entering developed economies may be seeking to acquire new capabilities operating in different institutional environments that can enhance their long term performance (Cantwell, 1992; Luo \& Tung, 2007). Quality of host country institutions may play a more important role in attracting relatively less experienced Chinese MNEs (Guler \& Guillén, 2010). In other words, Chinese MNEs' FDI decisions to invest in developed countries may be highly contingent on host government policies toward their FDI and well-established market supporting institutions (Schwens \& Kabst, 2011). Home country government support through direct intervention, i.e. putting pressure on developed host countries may have a limited impact on Chinese firms' entry in these countries (Lin, 2010). Developed country governments may be cautious, if not suspicious, about the Chinese government's strategic intentions behind the entry (Hoskisson, Wright, Filatotchev \& Peng, 2013). For example, when the Chinese company Wanxiang Group purchased the bankrupt lithium ion battery 
maker A123, this raised concerns about sensitive battery technology being acquired that could have military applications, although the deal was eventually approved (Bruno \& Wiersema, 2013). In another example, China's largest telecommunications equipment company, Huawei, abandoned its proposed acquisition of 3Leaf, a U.S. server technology company, following U.S. government concerns about Huawei's connections with Chinese security services (Freshfields Bruckhaus Deringer, 2011).

In sum, although home government FDI support policy and quality of host country institutions will reduce the importance of Chinese firms' prior international experience in a host country in facilitating an FDI entry, we expect home government FDI support policy plays a stronger substitutive role when firms choose to enter developing countries, while the quality of host country institutions has a stronger substitution effect when firms choose to enter developed countries. Hence, we propose:

Hypothesis 3a: The substitution effect of a Chinese firm's compliance with government FDI support policy reducing the importance of its prior international experience in a host country (HI) will be stronger when Chinese MNEs enter developing countries.

Hypothesis 3b: The substitution effect of high quality host country institutions reducing the importance of a Chinese firm's prior international experience in a host country (H2) will be stronger when Chinese MNEs enter developed countries.

\section{DATA}


We constructed a panel dataset of outward FDI by firms listed on the Shanghai and Shenzhen Stock Exchanges of China. We start in 2002 because FDI from China surged after China's access to the WTO in 2001 (MOFOM, 2009). To obtain longitudinal data, we focus on firms listed in all eight years during 2002-2009. ${ }^{1}$ We define a subsidiary as any entity where the listed firm holds at least 20 percent of the equity ${ }^{2}$. We manually collected information on overseas subsidiaries of listed firms from annual reports. ${ }^{3}$ We identify the establishment of an overseas subsidiary by comparing full subsidiary lists of a given firm for consecutive years. If an overseas subsidiary appeared in firm $i$ 's annual report of year $t$ but not in that of year $t-1$, we further check the annual report and other documents about the firm for year $t$ to confirm the establishment year for the subsidiary. As shown in Table 1, Hong Kong and the Caribbean tax havens (e.g. Bermuda, Virgin Island, and Cayman Island) are among the top destinations.

$$
\text { ***Table } 1 \text { near here*** }
$$

We compile data on the basic economic characteristics of host countries from the World Development Indicators (WDI) database. We restrict our sample to countries with three basic economic characteristics (Population, GDP growth rate, and GDP per capita) available for years between 2000 (the earliest year needed to calculate three-year moving average of variables to smooth the effects of abnormal fluctuation in economies) and 2008 (the year prior to 2009) from the most current version of the WDI. This step drops seven countries which had received investment from the sample firms. ${ }^{4}$ 
We exclude investment projects in Hong Kong, Singapore, Macau, and Caribbean tax havens (Bermuda, Virgin Island, and Cayman Island) because outward FDI from China to these destinations may be driven by tax considerations (Hampton \& Christensen, 2002). We restrain our analyses to a sample of subsequent entries which represents the location choices of new entries by 74 firms among 53 countries in which they had invested in previous years. ${ }^{5}$ This approach is more consistent with the focus of our hypotheses on the interaction effects between a firm's prior entry experience in a host country and the host country's institutions as well as home country government's supportive policy towards investment in the host country (Chang \& Rosenzweig, 2001). Empirically, firms and host countries that do not experience any entry over the entire time period under consideration ought to be excluded from the choice set because mixing heterogeneous firms (investors and non-investors) and host countries (investees and non-investees) risks introducing a serious bias in estimations due to unobserved heterogeneity (Martin, Swaminathan, \& Tihanyi, 2007). The dataset includes 124 firm-investment-years, defined as a year in which a given firm made one or more overseas investments. Each firm investment year consists of multiple records, with each record representing a potential investment choice. The number of records in a firm investment year increases with each successive year due to the increasing number of countries following by firms' initial investments. Following the literature, we define developed countries and developing countries according to the United Nations' classification which categorizes countries into developed and developing countries reflecting their basic economic conditions (Cuervo-Cazurra \& Genc, 2008; Luo \& Wang, 2012). Our dataset comprises 5068 observations in the full sample, with 3335 and 1733 observations for investment projects in developing and developed countries, respectively. 


\section{Dependent Variable}

The dependent variable, Entry dummy, equals 1 if a sample firm has conducted a new subsequent entry in a given host country in a given year, and 0 otherwise. A firm may have multiple entries in a particular country in a single year. In these cases, the dependent variable is coded as 1 no matter how many entries a firm had made in a particular country in a single year.

\section{Independent Variables}

Host country institutions. To operationalize host country institutions that affect the contingency value of firms' prior entry experiences, we choose among well recognized institutional environment indicators which are directly related to investment risks of inward FDI. We first adopt the widely used Worldwide Governance Indicator (WGI) constructed by Kaufman, Kraay, \& Mastruzzi (2009). WGI is widely used in recent studies on the impact of institutions on firms' internationalization decisions (e.g., Cantwell, Dunning, \& Lundan, 2010; Gu \& Lu, 2011; Slangen \& Beugelsdijk, 2010). Among six dimensions of WGI, we use Regulatory quality in our main analyses because it directly captures the soundness of policies and regulations that permit and promote private sector development, including inward FDI (Kaufman, Kraay, \& Mastruzzi, 2009). The scores of Regulatory quality range between -2.5 to 2.5 , with the higher the score, the sounder the policies in host countries related to investment, including promotion of inward FDI. In robustness checks, we also use other dimensions of WGI and other widely used alternative indicators to proxy the quality of host country institutions. 
Home country supportive policy. To capture the effect of home country government support on a firm's FDI decision, we construct a dichotomous variable, which equals 1 if the industry of a firm's investment accords with the Chinese government guidance for FDI to a given country in a given year, and 0 otherwise. Since the implementation of the "go global" strategy in 2000, the Chinese government has established the Guidance Catalogue of Countries and Industries for Overseas Investment ("Guidance" hereafter) as a set of guidelines for Chinese FDI to help inform firms' foreign entry decisions (Buckley et al., 2010; Luo et al., 2010). The Guidance covers countries and regions in which the Chinese government encourages Chinese firms to invest. The Guidance also identifies preferred industries in each host country to which the Chinese government encourages FDI by Chinese firms. For example, the Chinese government encourages investments in Kuwait, but only in oil and natural gas, chemical and cement manufacturing industries. Considering Kuwait as a host country, Home country supportive policy equals 1 if a firm's FDI is in the one of the three industries, and 0 otherwise. Three versions of the Guidance were issued in 2003, 2005, and 2007, respectively. We use the latest version of the Guidance that relates to the entry year. For example, for year 2008, we use the Guidance released in 2007 to measure whether a firm's entry is supported by the government policy.

Prior entries by the focal firm. To proxy a firm's international experience, we used Prior entries by the focal firm which equals the logarithm of the number of prior FDI entries into a particular host country by the firm accumulated to year $t$. The measure captures a firm's accumulated direct investment knowledge in a specific host country which may encourage the firm to further invest in that country (Dowell \& Killaly, 2009). 


\section{Control Variables}

Exogenous uncertainty means that some uncertainties, such as political risks, economic uncertainty and exchange rate uncertainty, cannot be resolved through the internal efforts of firms (Cuypers \& Martin, 2010) and should be controlled for in estimation models. We control for exogenous uncertainty and market attractiveness of host countries with a set of country-level control variables obtained from the WDI. Population, GDP per capita, and GDP growth rate are used as proxies of the size, development level, and economic growth in host countries which represents market attractiveness of host countries (Holburn \& Zelner, 2010; Martin, Salomon \& Wu, 2010).

Previous studies found that various kinds of cross-national distance affect firms' overseas investments (e.g., Berry, Guillen \& Zhou, 2010; Holburn \& Zelner, 2010; Martin et al., 2010). We include cross-national distance measures developed by Berry et al. (2010) to capture their possible effects on location choices. Economic distance is defined as differences in economic development and macroeconomic characteristics; Connectedness distance is measured as differences in tourism and internet usage; Political distance equals differences in political systems; Administrative distance is measured as differences in language, religion and legal system; and Geographic distance is calculated as the distance between geographic centers of countries.

Existing literature also found that, in general, countries tend to use bilateral negotiations to facilitate FDI (Ramamurti, 2001). Bilateral investment treaties (BITs) play an important role in overcoming FDI restrictions. Host countries use BITs to attract inward FDI through upgrading and improving quality of investment-related institutions, while home countries use BITs to promote 
outward FDI by their firms (Dunning, 2009). We measure the existence of BITs between China and potential host countries with a dummy variable, Bilateral investment treaty, which equals 1 if a BIT was in place in a given year between China and a host country, and 0 other wise.

We control for three additional sources of international learning experience which enable the focal firm to obtain knowledge and to deal with risks in host countries (Henisz \& Delios, 2001). First, we capture a firm's experience of exporting to a country with Value of export by the focal firm defined as the logarithm of a firm's exports (in U.S. dollars) to a specific country. We obtain information on firms' exports and destinations from the Customs General Administration of China (CGAC) database. The CGAC database covers all trade transactions conducted by Chinese firms. We match listed firms and trading firms in the CGAC by firms' names and registration addresses. This matching method follows common practice that links firm-level data with transaction-level trade data (Bernard, Jensen, Redding \& Schott, 2007). The CGAC database records all export transactions conducted by firms to different countries, and we calculate a firm's exports to a destination which reflects the firm's international experience through exporting (Campa \& Guillen, 1999). Second, we control for the possibility for a firm to learn from other firms' exporting behaviors to a country with Value of export by other firms, which equals the logarithm of other firms' export sales to a specific country. Third, we include Prior entries by other firms in a country, which is the logarithm of the accumulated number of entries in the country by all other Chinese firms excluding the focal firm. This measure captures the spillover effect of knowledge about the host country accumulated by Chinese firms. To reflect a more representative picture of prior experience by other firms, we use data collected by the Ministry of Commerce of China and published in Statistical Bulletin of China's Outward Foreign Direct 
Investment (MOFCOM, 2009). The latter two measures were used to capture the impact of vicarious learning (Guillén, 2003; Salomon \& Martin, 2008).

We also control for Return on assets, Sales, and Firm age because more profitable, larger, and older firms typically have more resources for outward FDI (Dowell \& Killaly, 2009). We control for Government equity share and Foreign equity share, defined as equity shares owned by government agencies and foreign investors, respectively. Chinese government support for FDI may differ for Chinese firms with different government equity shares. Foreign equity share should be controlled for because foreign investors could be an important source of knowledge of global markets. Thus, controlling for ownership structure mitigates potential unobserved heterogeneity in estimations.

Following Holburn \& Zelner (2010), we use a three-year moving average window as our main regressors, with five exceptions: Prior entry experience of the firm and Prior entry experience of other firms are measured with a one year lag because these two variables represent accumulated values over all previous years to year $t-1$. The third exception is Home country supportive policy which measures the degree of a potential entry's compliance with the "Guidance". As changes in the "Guidance" for various years are incremental, a preferred country-industry combination in previous versions of "Guidance" is also included in the current guidance, and like prior entry experience variables, we do not need to construct the variable as a moving average. The fourth exception is Cultural distance because it does not change much over years and is only available for some years in the sample period. The fifth variable which is not constructed as a moving average is the Lagged entry dummy, which is the lagged dependent variable on the right-hand side included to address possible residual serial 
correlation in robustness checks (Holburn \& Zelner, 2010). We restrict our moving average window to three years for two reasons. First, for the construction of Value of export by the focal firm and Value of export by other firms, we only have access to data starting from year 2000. Second, for a few firms that listed in the early years of the sample period, we only have financial information (Return on assets, Sales, Government equity share and Foreign equity share) for three years before the listing.

\section{METHODS}

As the data has a panel structure with temporal dependence among annual observations for a given firm, and thus fixed effects models, including conditional fixed effects logit model and unconditional fixed effects logit model, are suitable to address these unobserved heterogeneities (Denis, Denis, \& Yost, 2002). Compared to the conditional fixed effects model, the unconditional fixed effects model allows us to keep firm-investment-year groups for which some records have missing data and allows us to include interactions containing variables of host/home countries and firm experiences (Holburn \& Zelner, 2010; Katz, 2001). The unconditional fixed effects logit models account for unobserved heterogeneity among firms and unobserved temporal shocks because dummy variables were included for each firm and each year (Allison, 2009). Therefore, to account for unobserved heterogeneity among industries and host countries, we also included a set of industry dummies and host country regional dummies.

To address the possibility of autocorrelation and unobserved heterogeneity of our data, we include a lagged dependent variable on the right-hand side of models (Holburn \& Zelner, 2010). To avoid specification error, we followed Shamsie, Martin and Miller (2009) and employed an 
instrument variable for the lagged dependent variable which is calculated by regressing the lagged (t-1) dependent variable against all lagged (t-1) independent variables in the models, and then substituting the lagged dependent variable with the predicted value (the instrument variable).

\section{EMPIRICAL RESULTS}

Table 2 presents descriptive statistics and correlations of the sample of subsequent entries. Most host country variables, except Political distance, Administrative distance, and Geographic distance, are significantly correlated with the dependent variable. Most firm-level control variables, with the exception of Return on assets, Firm age, Government ownership share, and Foreign ownership share, are significantly correlated with the dependent variable. All previous internationalization experience variables, including other firms and the focal firm, are positively and significantly correlated with the dependent variable. Home country supportive policy and host country institutions (Regulation quality) are all positively and significantly correlated with the dependent variable.

$$
\text { ***Table } 2 \text { near here*** }
$$

We report the estimated coefficients and their standard errors of fixed-effect logit models in Table 3. Column 1 in Table 3 contains results for the basic unconditional fixed effect specification including an instrument variable of the lagged dependent variable and all independent variables except for two interaction terms of main interests. The market attractiveness and distance variables are largely insignificant probably because their variances across years are not large enough. The host country institution variable (Regulation quality) is positively correlated with the dependent variable, 
but not statistically significant. Among control variables, Government ownership share has a positive and significant coefficient, implying the government plays important roles in Chinese firms' outward FDI decisions. The coefficient of Home country supportive policy is positive and significant, showing that alignment with the home country's supportive policy significantly increases the probability of firm entry into a host country. Previous export experience and investment experience in a host country by the focal firm and other firms have positive but in significant impacts on the firm's entry decision.

$$
\text { ***Table } 3 \text { near here*** }
$$

Testing $\mathrm{H} 1$ and $\mathrm{H} 2$ with the full sample, we introduce the hypothesized interaction terms one by one in Columns 2-3, and include both hypothesized interaction terms for H1 and H2 in Column 4. Columns 5 - 6 of Table 3 represent the results for $\mathrm{H} 3 \mathrm{a}$ and $\mathrm{H} 3 \mathrm{~b}$ using developing countries and developed countries subsamples, respectively. Results in Column 2-4 show that both home country support policy and host country institutions variables have strongly significant and negative moderating effects on the inter-relationship between the firm's prior entry experience and the probability of firm entry into a host country, in line with our theoretical expectations in hypotheses 1 and 2. The coefficient of the interaction between prior entries by the focal firm and home country supportive policy for the subgroup of developing countries (Column 5 of Table 3 ) is negative and statistically significant, while the interaction for the subgroup of developed countries (Column 6 of Table 3) is negative but statistically insignificant. The finding is consistent with $\mathrm{H} 3 \mathrm{a}$ which predicts a substitution effect of a firm's compliance with home country government FDI support policy. However, the coefficients of the interaction between prior entries by the focal firm and host country 
institution in both subgroups of countries are statistically insignificant. Therefore our results do not seem to support to Hypothesis $3 b$.

As the coefficients of interactions in nonlinear models do not represent the magnitude of the conditional effects (Holburn \& Zelner, 2010), we supplement the discussion of the coefficients reported in Table 3 with further analysis based on figures constructed using the simulation-based approach developed by King, Tomz, and Wittenburg (2000) and Zelner (2009). This approach can visually compare the predicted probabilities associated with different combinations of independent variable values, and can test whether the difference in predicted probabilities is statistically different from zero by constructing a confidence interval. Therefore, it provides a more fine-grained analysis of the hypothesized relationships tested in the regression analysis.

$* * *$ Figure 1 near here***

Figure 1(a) shows how the predicted probability of firms entering into a host country changes in association with firms' prior entry experiences in the host country when the entry is aligned with home country supportive policy (indicated by a dashed line) and when the entry is not aligned with home country supportive policy (indicated by a solid line). Figures 1(a) also includes the 95 percent confidence intervals for the predicted probabilities. Both probability curves were upward sloping and the dashed line is less steep than the solid line, suggesting the positive relationship between prior entries by the focal firm and the probability of entry is less pronounced when the potential entry is aligned with the home country supportive policy, as we expected. As the confidence intervals surrounding the predicted probabilities for the dashed and the solid lines overlap in Figure 1(a), it is 
hard to tell from the figure alone whether the overlap is great enough so that the null hypothesis cannot be rejected. Thus, we plotted Figure 1(b) of the difference in predicted probabilities associated with increasing prior entries by the focal firm. The dotted symbols and the circled symbols indicate that the difference is statistically significantly different from zero at levels of 95 and 90 percent, respectively. The downward-sloping curve in Figure 1(b) indicates that the magnitude of the difference in probabilities of entries that are aligned with the home country supportive policy and those that are not aligned decreases in association with firms' prior entry experiences. Meanwhile, significance symbols indicate that home country support has a significant effect in reducing the importance of prior entry experience in entry decisions when a firm has relatively fewer prior entry experiences (with 2 or less prior entries), rather than along the whole range of prior entry experiences.

Figure 1(c) shows how the predicted probability of firms' entering into a host country changes in association with firms' prior entry experience in the host country with well-developed or underdeveloped institutions (measured as one standard deviation above or below the mean of Regulation quality, respectively). Again, both probability curves were upward sloping, indicating that firms are more likely to enter into a host country in which their previous entry experience is higher. Meanwhile, the upward sloping curve when a host country has better-developed institutions (the dashed line) is less steep than that when a host country has less-developed institutions (the solid line), suggesting the positive relationship between prior entries by the focal firm and the probability of entry is less pronounced when a host country has well established institutions, as we expected. Figure 1(d) plots the difference between predicted probabilities in Figure 1(c). It shows that although the downward sloping curve indicates a negative moderating effect of host country institutions on prior 
entry experiences, the role of better host country institutions is only significant for firms with a modest number of prior entry experiences ( 3 to 7 prior entries). This result may mean that, in contrast to the case when firms have little prior entry experience, better host country institutions have a stronger effect in reducing the importance of prior entry experiences when firms become more familiar with host country institutions. This is important nuanced evidence related to our H2.

H3a predicts that the substitution effect of a firm's compliance with home country government FDI support policy on the importance of its prior international experience in a host country will be stronger when the firm enters developing countries. Indeed, predicted entry possibilities when a potential entry into developing countries is aligned with the home country supportive policy (the dashed line) is less steep than that when a potential entry is not aligned (the solid line) in Figure 1(e), while the plotted difference between predicted probabilities in Figure 1(f) has a downward trend. However, Figure 1(f) also shows that the downward trend is very flat for firms with less than two prior entry experiences, but that the downward trend is reversed for firms with more than three prior entry experiences. Thus, although the coefficient of the interaction term between prior entries by the focal firm and home country supportive policy for the subgroup of developing countries (Column 5 of Table 3) is negative and statistically significant, the simulation based figure shows that $\mathrm{H} 3 \mathrm{a}$ is supported only within a narrower range of values regarding prior entry experiences.

Finally, Figures $1(\mathrm{~g})$ and $1(\mathrm{~h})$ depict the moderation effect of host country institutions on the importance of prior international experience when the firm enters developed countries. In Figure 1(g), the upward sloping curve when a host country has better-developed institutions (the dashed line) was 
less steep than that when a host country has less-developed institutions (the solid line), suggesting that the positive relationship between prior entries by the focal firm and the probability of entry is less pronounced when a host country has well established institutions. In Figure 1(h), the difference between predicted probabilities is statistically significant over the whole range of the downward sloping curve. The results based on simulation are in line with our predictions in $\mathrm{H} 3 \mathrm{~b}$ and reveal more fine-grained information than the coefficient of the interaction term presented in Column 6 of Table 3.

\section{Robustness Tests}

To examine the sensitivity of our results to model specifications, we conducted a series of robustness tests. First, among the key investment-supporting institutions in host countries are factors associated with property rights, which constrain government expropriation of firms, and contracting institutions, which protect firms from infringement by private businesses (Acemoglu \& Johnson, 2005). A lack of such fundamental institutions generates hazards of expropriation and imposes obstacles to investment by foreign firms. We use two variables to measure expropriation risk and political risk faced by inward FDI in host countries. We use the ICRG investment profile, which is described as the assessment of investment risk due to contract viability/expropriation and profits repatriation to measure the expropriation risk faced by inward FDI in host countries. The ICRG investment profile is an index from the International Country Risk Guide (ICRG) which has been used in a number of papers on FDI and institutional environments (e.g., Durnev, Errunza \& Molchanov, 2009; Fogel, 2006), and ranges from 0 (high expropriation risk) to 12 (low expropriation risk). We also use the POLCON index, which reflects the extent to which the partisan composition of a 
country's formal branches of government (i.e., executive, legislative, and judicial) constrains any one institutional player from unilaterally affecting policy changes (Henisz, 2000). POLCON is among the most widely used variables to measure policy risk in countries (Holburn \& Zelner, 2010), and ranges from 0 (high political risk) to 1 (low political risk). The results of the fixed effect and multilevel logit models using ICRG investment profile and POLCON are similar to those in the main analyses.

Second, we checked the robustness of results using five other dimensions of the WGI separately (i.e., Rule of law, Government effectiveness, Control of corruption, Voice and accountability, and Political stability) and as a combined factor of six dimensions (these five plus Regulation quality from above) obtained after using factor analysis ( $\mathrm{Gu} \& \mathrm{Lu}, 2011)$. We also added more control variables that may affect a host country's attractiveness. These variables included Ratio of current account balance as percentage of GDP, Ratio of government expenditure to GDP, Ratio of trade to GDP. We also controlled for Financial distance, defined as differences in financial sector development, and Cultural distance constructed by Berry et al. (2010) using items from the World Values Surveys (WVS). Because WVS covers different countries in various years, using moving averages will restrict the variable to a few countries. As cultural dimensions do not change as fast as other institutions, we used the most recent value of Cultural distance in our analyses. Using alternative measures of host country institutions and adding new controls do not change results of the interaction coefficients hypotheses.

Third, as recent studies have shown the importance of supranational regional factors in FDI location choices (Flores, Aguilera, Mahdian \& Vaaler, 2013), we used Prior entries in the same 
region by the focal firm to proxy entry experiences accumulated in the same region by a focal firm, and use Prior entries in the same region by other firms to proxy entry experiences in the same region accumulated by other firms. We used both the geography-based regional grouping scheme based on continents and the culture-based regional grouping scheme developed by Ronen \& Shenkar (1985) to categorize countries into regional groups. Results of regional experiences supported $\mathrm{H} 2$ but not other hypotheses. The results further confirm that home country supportive policies are country specific, and cannot match well with region level experiences. However, institutions in host countries in the same region are more or less similar, and thus prior experiences accumulated in the same region are more relevant to entry decision in specific countries in the same region.

Fourth, given our focus on the moderating effect of home country government support and host country institutions on the relationship between firms' prior entry experience and FDI decisions in a host country, we use multilevel logit models (Rabe-Hesketh \& Skrondal, 2008) as a robustness test to supplement our analysis based on the fixed effects logit model The results of multilevel logit models are very similar to the results of fixed effect logit models reported above. Because of space constraints the results of these robustness tests are not presented but are available upon request. ${ }^{6}$

\section{DISCUSSION}

Our study focuses on the interrelationship between the prior international experience of Chinese firms, FDI promotion policies of the home country, and the quality of host country institutions, and conducts a detailed analysis of how home government support and host country institutions interact with prior international experience in foreign entries. We found evidence which suggests that home 
country government support enhances organizational capabilities to take risks when relatively less experienced Chinese firms venture abroad. The quality of host country institutions tends to reduce the importance of prior international experience, thus attracting less experienced latecomers, such as Chinese firms. Our findings provide partial support for the perspective that home government support and host country institutions can offset the need for prior international experience in EE firms' FDI activities. We have examined the importance of home government support and quality of host country institutions in the subsamples of developing and developed host countries. The results further reveal that home country government support tends to have a stronger substitutive effect on the prior entry experience of Chinese firms in developing host countries, whereas the quality of host country institutions has a stronger substitutive effect on international experience in developed host countries.

Our findings indicate that the importance of firms' prior international experience in FDI entries varies, depending on the institutional context of both home and host countries. This implies that inexperienced firms can seek home government support and select a host country with favorable institutional conditions in international expansion. Thus, internationalization, to a large extent, is no longer constrained by knowledge accumulated through conducting business abroad or vicarious learning at the firm level. Alternatively, home country government support and well-established host country institutions represent important contingency factors which affect the marginal benefits of experiential learning and the subsequent investment decisions. Therefore, the effects of prior entry experience are far from being universal across different home and host institutional environment, and they may be institutionally embedded both at home and abroad. This represents an important extension of KBV in the FDI context. 
Most previous studies based on the KBV were conducted at the firm level and proposed that knowledge accumulation, such as prior experience and knowledge acquisition through vicarious learning are cornerstones of firm internationalization (Johanson \& Vahlne, 2009; Kogut \& Zander, 1993; Martin \& Salomon, 2003). However, these studies did not take account of the role of macro-factors, such as home government support and host country institutions, as important contingencies which affect firms' risk-taking capabilities and the marginal benefits of experiential learning. On the other hand, IB research based on various contingency models tended to focus on the moderating/mediating roles of firm-level characteristics, such as absorptive capacity or R\&D intensity (Filatotchev \& Piesse, 2009; Filatotchev \& Wright, 2011). Extending the KBV, our research complements previous studies by systematically examining the moderating effect of the two macro-factors, and it helps bridge the boundary between organizational capabilities and contextual forces. This research setting enables us to address the contingency impact of government support and host country institutions on prior international experience. Focusing on the inter-relationship between government support, host country institutions and prior experience, we go beyond a simplified application of KBV to EE MNEs and gain important insights by broadening the KBV beyond the boundary of individual firms. In particular, our research suggests that the importance of prior experience is contingent on the institutional context of both home and host countries. Thus, the study fills an important research gap in the KBV in which institutional contexts or contingency factors are visible.

Further, our more fine-grained analysis based on empirical methodology suggested by King, Tomz and Wittenburg (2000) and Zelner (2009) indicates that institutional factors produce their 
moderating effect not along the whole range of the firm's prior entry experiences. For example, home country support has a stronger effect in reducing the importance of prior entry experience in entry decisions when a firm has relatively fewer prior entry experiences. Likewise, host country institutions have a significant moderation effect mainly when firms have accumulated a modest number of prior entry experiences. This fine-grained analysis indicates that the firm's prior experience and the two institutional factors are not orthogonal, and the experience may define the relative salience of institutional effects. For example, better host country institutions have a stronger effect in reducing the importance of prior entry experiences mainly when firms become more familiar with host country institutions. This finding points to an important avenue of future research which may focus on potential inter-dependencies between firm-level knowledge accumulation and the impact of macro-institutional factors.

Our findings contribute to a better understanding of the special characteristics of Chinese MNEs with regard to their strategic behavior in terms of foreign entry choices (Mathews \& Zander, 2007). The results have enabled us to show that home country government support and host country institutions help enhance risk-taking capabilities and reduce firms' reliance on prior international experience. These contingency factors may help Chinese firms to engage in internationalization in a large step instead of an incremental fashion. Hence, this study enriches our understanding of how EE firms internationalize in the distinctive institutional context of both home country and host countries. Such analysis also enables us to bring the institutional context more explicitly and appropriately into the KBV and enhances our understanding of how firms' prior international experience is contingent on macro factors, jointly shaping the location choices of Chinese MNEs. Our study also fills a gap in 
the prior literature which separately examines either host country environments or home government support or prior international experience. We have obtained new insights in terms of substitutes between home country government support, host country institutions and firms' prior entry experiences through focusing on the interrelationship between these factors. Our findings indicate that entry decisions are an outcome of a complex interplay of organizational capabilities and institutional factors in both home and host countries.

Our study helps advance IB theory which has either focused on the impact of firm-specific advantage on international expansion, but has overlooked or taken the contingency effect of home and host institutional contexts in firm internationalization as given, or examined the impact of institutions in isolation. Our analysis provides a more complete account of factors affecting FDI entries and shows that well-established host country institutions and supportive policies by the home government represent capability-enhancing mechanisms through which less experienced firms are able to reduce the reliance for experiential knowledge needed for entering a host country. Our findings challenge the dominant view about the importance of accumulated experience in conventional internationalization theory. The relationship between foreign entries and the impact of firms' international experience is not universal but depends on institutional contexts. Our results also show the importance of incorporating both home and host country characteristics in internationalization strategy studies (Holburn \& Zelner, 2010). These aspects are particularly important for subsequent entries which have been largely neglected. More specifically, our findings show that the level of development has a significant impact on the salience of the moderating roles of both home government support and host country institutions. This is consistent with theoretical arguments put forward in recent work by 
Hoskisson et al. (2013) who suggest that researchers should focus on macro institutional and infrastructure differences between countries. Our findings that the institutional effects differ between developed and developing economies point to the need for future research based on more fine-grained analysis of the complex interface between firm-level and country-level factors.

Though based on China, our findings may have implications for practitioners and policymakers in EEs. We suggest that governments should continue to develop more fine-grained policies targeted at firms with the potential to internationalize but have yet to do so or have done so but only in a limited way. Policies may also need to be more fine-grained in terms of the countries and industries for which support is offered given the institutional environment of the host country. Further consideration should be given to the extent to which bilateral agreements between home and host country governments can facilitate a more accommodating host environment (Rangan \& Sengul, 2009). Our findings help managers of MNEs understand the conditions necessary to conduct FDI and show that government support is an important contingency factor for newcomers to engage in FDI. Hence, managers should carefully assess host and home institutional factors when making entry decisions.

Our results imply that Chinese firms are able to utilize institutional factors to compensate for the lack of experience about host countries. This suggests that it may be less important for internationalizing Chinese firms to accumulate international experience. Rather, seeking home and host country institutional support when making the location choice for foreign entry may be an important strategy that helps deal with exogenous and endogenous uncertainty (Cuypers \& Martin, 
2010). For example, information on host countries' economic climate provided by home country FDI promotion agencies may help Chinese firms to assess economic uncertainty and exchange rate uncertainty facing them when entering the host country. Knowledge about a host country in terms of culture, local norms and values provided by home country government agencies may also assist Chinese firms in resolving culture uncertainty when operating in the host country otherwise they would have achieved it through a time-consuming learning by doing process. In addition, well-established host country institutions will help Chinese firms to understand how local institutions work and help reduce local institutional uncertainty. Thus, institutional contexts of both host and home countries are more than background conditions and play an important role in the internationalization strategies of Chinese firms.

Although it is important to examine how government policy affects Chinese firms' internationalization strategies, given the increasing importance of the Chinese economy, the uniqueness of this form of state support may limit the generalizability of our study. However, we know from previous literature that state support may have various forms and different contingency impacts, in both developed and emerging economies (e.g., Aharoni \& Ramamurti, 2008; Hoskisson et al., 2013; Kumar, 2007). Our findings highlight that the effect of state support may be context specific. We show that home country state support for sectoral FDI into particular countries is particularly valuable for less experienced firms from EEs when making subsequent entries. In contrast, other studies in developed countries, such as Canada, examining the direct effect of home country policies aimed at inward FDI and outward FDI have shown that while general policies may be indifferent 
(Globerman \& Shapiro, 1999), the effect of sector specific policies varies significantly between sectors (Shapiro \& Globerman, 2003).

\section{LIMITATIONS}

As all studies, ours has several limitations that provide opportunities for further research. First, the study was restricted to Chinese firms and one dimension of the home country institutional context, that is, the Chinese government's FDI support policy. It should also be noted that China may represent an exceptional case in terms of state support since the Chinese OFDI Guidance is rather a unique policy mechanism. Nevertheless, focusing on the interrelationship between home government support and firm-level characteristics instead of the direct impact of FDI policy on the aggregate level of outward FDI (e.g. Globerman \& Shapiro, 1999), our study reveals a novel dimension of FDI policy and calls for more research on the complex interface between different forms of state support and firm characteristics, and how these jointly affect the business strategy of firms from EEs. Additionally, our measure of whether the sample firms followed home government guidance was based on subsequent investments in policy supported industries in a host country. However, the total number of subsequent investment projects is relatively low which leads to a rather low mean for the number of investments following home country support policy variable in the overall sample. The total number of investments in policy supported industries and countries is rather substantial indicating that the Chinese state guidance affects internationalization decisions of companies. Further research could use survey data to measure government supportive policies in a more fine-grained way, such as managers' perceptions toward risks associated with outward FDI given specific government support 
Second, our dependent variable is not the performance of foreign subsidiaries but the number of new subsidiaries established annually in particular foreign countries. In view of the considerable steer given by the Chinese government to FDI location choices, many overseas subsidiaries may be established to suit national interests rather than to exploit profitable opportunities. Further research is needed to examine the performance of subsequent entries. Third, while we recognize that Chinese firms also have opportunities to learn how to deal with institutions in host countries at home, as our data is limited to one home country we are unable to capture the effects of learning from operating in a home country with weak institutions. A related point is that Chinese firms may also learn from other firms' prior international experience. Though we controlled for the impact of vicarious learning (Henisz \& Delios, 2001), we were unable to find evidence of the interrelationship between institutional factors and vicarious learning. Further research is needed to pursue this important area and examine whether Chinese firms have learnt from their counterparts at home and abroad. In particular, the channels through which Chinese firms learn from other firms need to be identified using both secondary and qualitative data. The other related point is that our research mainly focused on the inter-relationship between prior experience, home government support and host country institutions, so we did not distinguish the internal process of learning and government-sponsored learning. Future research should investigate whether different learning processes or mechanisms have differing impacts on foreign entry decisions. Fourth, while our analysis focuses on the establishment of a subsidiary in particular countries, we do not have information on the entry mode strategy of the sample firms. An entry mode strategy represents an important strategic response to host country institutions and home country government support. Further analysis may attempt to explore 
differences between the modes of foreign market entry and examine how an entry mode strategy interacts with contextual forces in both home and host countries. Fifth, we acknowledge that related knowledge (from either the home country or another host country) may be leveraged in a new host country (Garcia-Canal \& Guillen, 2008; Holburn \& Zelner, 2010). Further research is needed to extend consideration of this knowledge to the issues addressed in this paper. Sixth, we did not examine how host countries may use policy or set up regulations to attract or discriminate against FDI from EE economies such as China. Further research is needed to take this possibility into account by collecting qualitative data through interviewing government officials. Finally, our theoretical approach assumed that firms adopt rational, efficiency-centered decision-making. However, FDI decisions may be socially constructed and driven by managers' perceptions of the legitimacy of entering certain markets as set down in home government guidance. While this was beyond the scope of our study, further research adopting a socially constructed approach may be worthwhile.

\section{CONCLUSION}

Using a panel dataset of Chinese listed corporations, we have extended previous research on outward FDI from an emerging economy by examining the interplay between home government support, host country institutions and firms' prior entry experience on foreign entry decisions by Chinese firms. The results indicate that home government support and host country institutions reduce the importance of firms' prior international experience. Our findings provide support for the perspectives that the nature of the institutional context can affect knowledge and risk-taking capabilities needed for FDI entries in host countries. We extend the boundary of KBV by focusing on the interrelationship between a host 
country's institutional environment, the home government's guidance of FDI and firms' prior international experience. We show that home country government support and well-established host country institutions represent capability-enhancing mechanisms that significantly moderate the impact of firms' prior international experience in FDI entries. 


\section{NOTES}

${ }^{1}$ It is possible that a balanced panel which excludes delisted firms during the sample period may cause survival bias. However, unlike some other countries (e.g., the U.S.) where delisting is common, delisting is very rare in China. During 2002-2012, there were only 75 firms delisted from China's stock exchanges. In a robustness check, we coded outward FDI of firms delisted during the sample period and replicated analyses reported in the paper, and found robust results.

${ }^{2}$ Twenty percent of equity is the threshold of disclosure of subsidiaries in annual reports required by Chinese authority. Ownership percentages in overseas subsidiaries established during the period of 2003-2009 range from $23.3 \%$ to $100 \%$. We also use $50 \%$ and $100 \%$ equity as alternative thresholds for robustness check, and found the results are robust to the results using $20 \%$ as the threshold.

${ }^{3}$ Annual reports are collected from reliable data sources including the Shanghai and Shenzhen Stock Exchanges, the China Security Regulation Committee (CSRC), websites of listed firms, and database of leading commercial business information providers (e.g., Wind and SinoFin).

${ }^{4}$ These countries include Afghanistan, Antigua and Barbuda, Democratic Republic of Congo, Cayman Islands, Republic of Korea, Romania, and British Virgin Islands.

${ }^{5}$ Following the suggestion of a reviewer, we also construct a sample of firms that make investment in a given year among countries that had received investment from any firm in the sample until the year t. The sample comprises 347 firm-year groups. The results of this robustness test are consistent with results for the sample reported in the paper.

${ }^{6}$ Given that the U.S. has received by far the largest number of entries by the sample firms, we excluded the U.S. from the sample and found the results to be as robust as those for the full sample including the U.S.

\section{ACKNOWLEDGEMENTS}

We are grateful to the Editor-in Chief John Cantwell, Xavier Martin and anonymous reviewers for their insightful comments. 


\section{REFERENCES}

Acemoglu, D., \& Johnson, S. 2005. Unbundling institutions. Journal of Political Economy, 113(5): 949-995.

Aharoni, Y., \& Ramamurti, R. 2008. The internationalization of multinationals, in Jean J. Boddewyn (ed.) International Business Scholarship: AIB Fellows on the First 50 Years and Beyond (Research in Global Strategic Management, Volume 14), Emerald Group Publishing Limited, pp.177-201

Allison, P. D. 2009. Fixed Effects Regression Models. Newbury Park, CA: Sage.

Amit, R., \& Schoemaker, P. 1993. Strategic assets and organizational rent. Strategic Management Journal, 14(1): 33-46.

Anand, J., \& Delios, A. 1997. Location, specificity and the transferability of downstream assets to foreign subsidiaries. Journal of International Business Studies, 28(3):579-603.

Bernard, A. B., Jensen, J. B., Redding, S. J., \& Schott, P. K. 2007. Firms in international trade. Journal of Economic Perspectives, 21(3): 105-130.

Berry, H., Guillen, M. F., \& Zhou, N. 2010. An institutional approach to cross-national distance. Journal of International Business Studies, 41(9): 1460-1480.

Bruno, G., \& Wiersema, A. 2013. Where's the money: Chinese investments in U.S. ABC World News, June 7, 2013.

Buckley, P. J., Clegg, J. L., Cross, A. R., \& Voss, H. 2010. What can emerging markets learn from the outward direct investment policies of advanced economies? In K. Sauvant, , W. Maschek, \& G. McAllister (Eds), Foreign direct investment from emerging markets: The challenges ahead. London: Palgrave Macmillan.

Campa, J. M., \& Guillen, M. F. 1999. The internalization of exports: Firm- and location-specific factors in a middle-income country. Management Science, 45(11): 1463-1478.

Cantwell, J. 1992. The theory of technological competence and its application in international production. In McFeteridge, D. (ed). Foreign investment, technology and economic growth. Calgary: University of Calgary Press, 33-67.

Cantwell, J., Dunning, J. H., \& Lundan, S. M. 2010. An evolutionary approach to understanding international business activity: The co-evolution of MNEs and the institutional environment. Journal of International Business Studies, 41(4): 567-586.

Casillas, J.C., \& Moreno-Menéndez, A. M. 2013. Speed of the internationalization process: The role of diversity and depth in experiential learning. Journal of International Business Studies, forthcoming.

Chang, S. J., \& Rosenzweig, P. M. 2001. The Choice of entry mode in sequential foreign direct investment. Strategic Management Journal, 22(8): 747-776.

Cui, J., \& Jiang, F. 2012. State ownership effect on firms' FDI ownership decisions under institutional pressure: A study of Chinese outward-investing firms. Journal of International Business Studies, 43(3), 264-284.

Cuervo-Cazurra, A., \& Genc, M. 2008. Transforming disadvantages into advantages: Developing-country MNEs in the least developed countries. Journal of International Business Studies, 39(6): 957-979. 
Cuypers, I., \& Martin, X. 2010. What makes and what does not make a real option? A study of equity shares in international joint ventures. Journal of International Business Studies, 41(1):47-69.

Denis, D. J., Denis, D. K., \& Yost, K. 2002. Global diversification, industrial diversification, and firm value. Journal of Finance, 57(5): 1951-1979.

Dowell, G., \& Killaly, B. 2009. Effect of resource variation and firm experience on market entry decisions: Evidence from U.S. telecommunication firms' international expansion decisions. Organization Science, 20(1): 69-84.

Dunning, J. H. 2009. Location and the multinational enterprise: A neglected factor? Journal of International Business Studies, 40(1): 5-19.

Durnev, A., Errunza, V., \& Molchanov, A. 2009. Property rights protection, corporate transparency, and growth. Journal of International Business Studies, 40(9): 1533-1562.

Eriksson, K., Johanson, J., Majkgard, A., \& Sharma, D. D. 1997. Experiential knowledge and cost in the internationalization process. Journal of International Business Studies, 28(2): 337-360.

Filatotchev, I., \& Piesse, J. 2009. R\&D, export orientation and growth of newly listed firms: European evidence. Journal of International Business Studies, 40(8): 1260-1276.

Filatotchev, I., \& Wright, M. 2011. Agency perspectives on corporate governance of multinational enterprises. Journal of Management Studies, 48(2): 471-486.

Flores, R., Aguilera, R. V., Mahdian, A., \& Vaaler, P. M. 2013. How well do supranational regional grouping schemes fit international business research models? Journal of International Business Studies, 44(5): 451-474.

Fogel, K. 2006. Oligarchic family control, social economic outcomes, and the quality of government. Journal of International Business Studies, 37(5): 603-622.

Freshfields Bruckhaus Deringer. 2011. Foreign acquisition of US assets thwarted on national security grounds. Freshfields Bruckhaus Deringer Briefing. February.

García-Canal, E., \& Guillén, M. F. 2008. Risk and the strategy of foreign location choice in regulated industries. Strategic Management Journal, 29(10): 1097-115.

Globerman, S., \& Shapiro, D. 1999. The impact of government policies on foreign direct investment: The Canadian experience. Journal of International Business Studies, 30(3): 513-532.

Globerman, S., \& Shapiro, D. 2003. Governance infrastructure and US foreign direct investment. Journal of International Business Studies, 34(1): 19-39.

Grant, R. M. 1996. Toward a knowledge-based theory of the firm. Strategic Management Journal, 17(Special Issue): 109-22.

Gu, Q. A., \& Lu, J. W. 2011. Effects of inward investment on outward investment: The venture capital industry worldwide 1985-2007. Journal of International Business Studies, 42(2): 263-284.

Guillen, M. F. 2003. Experience, imitation, and the sequence of foreign entry: Wholly owned and joint-venture manufacturing by South Korean firms and business groups in China, 1987-1995. Journal of International Business Studies, 34(2): 185-198.

Guler, I., \& Guillén, M. 2010. Institutions and the internationalization of US venture capital firms. Journal of International Business Studies, 41(2): 185-205.

Hampton, M. P., \& Christensen, J. 2002. Offshore pariahs? Small island economies, tax havens, and the re-configuration of global finance. World Development, 30(9): 1657-1673.

He, X., Brouthers, K., \& Filatotchev, I. 2013. Resource-based and institutional perspectives on export 
channel selection and export performance. Journal of Management, 39(1): 27-47.

Henisz, W. J. 2000. The institutional environment for multinational investment. Journal of Law, Economics and Organization 16(2) 334-364.

Henisz, W. J., \& Delios, A. 2001. Uncertainty, imitation, and plant location: Japanese multinational corporations, 1990-1996. Administrative Science Quarterly, 46(3): 443-475.

Henisz, W. J., \& Macher, J. T. 2004. Firm- and country-level trade-offs and contingencies in the evaluation of foreign investment: The semiconductor industry, 1994-2002. Organization Science, 15(5): 537-554.

Henisz, W. J., \& Zelner, B. A. 2005. Legitimacy, interest group pressures, and change in emergent institutions: The case of foreign investors and host country governments. Academy of Management Review, 30(2): 361-382.

Hitt, M. A., Beamish, P. W., Jackson, S. E., \& Mathieu, J. E. 2007. Building theoretical and empirical bridges across levels: Multilevel research in management. Academy of Management Journal, 50(6): 1385-1399.

Holburn, G. L. F., \& Zelner, B. A. 2010. Political capabilities, policy risk, and international investment strategy: Evidence from the global electric power industry. Strategic Management Journal, 31(12): 1290-1315.

Hoskisson, R., Wright, M., Filatotchev, I., \& Peng, M. 2013. Emerging multinationals from mid-range economies: The influence of institutions and factor markets. Journal of Management Studies, forthcoming.

Johanson, J., \& Vahlne, J-E. 2009. The Uppsala internationalization process model revisited: from liability of foreignness to liability of outsidership. Journal of International Business Studies, 40(9): 1411-1431.

Katz, E. 2001. Bias in conditional and unconditional fixed effects logit estimation. Political Analysis, 9(4): 379-384.

Kaufmann, D., Kraay, A., \& Mastruzzi, M. 2009. Governance matters VIII: Aggregate and individual governance indicators, 1996-2008. World Bank Policy Research Working Paper No. 4978.

King, G., Tomz, M., \& Wittenberg, J. 2000. Making the most of statistical analyses: Improving interpretation and presentation. American Journal of Political Science 44(2): 347-361.

Kogut, B., \& Zander, U. 1993. Knowledge of the firm and the evolutionary theory of the multinational enterprise. Journal of International Business Studies, 24(4): 625-645.

Kostova, T., \& Zaheer, S. 1999. Organizational legitimacy under conditions of complexity: The case of the multinational enterprise. Academy of Management Review, 24(1): 64-81.

Kumar, N. 2007. Emerging TNCs: trends, patterns and determinants of outward FDI by Indian enterprises. Transnational Corporations, 16(1): 1-26.

Lin, X. (2010). State versus private MNCs from China: Initial conceptualizations. International Marketing Review, 27(3), 366-380.

Lu, J., Liu, X., \& Wang, H. 2011. Motives for Chinese outward FDI: Firm resources, industry dynamics, and government policies. Management and Organization Review, 7(2): 223-248.

Lu, Y., Zhou, L., Bruton, G., \& Li, W. 2010. Capabilities as a mediator linking resources and the international performance of entrepreneurial firms in an emerging economy. Journal of International Business Studies, 41(3): 419-436.

Luo, Y., \& Peng, M. 1999. Learning to compete in a transition economy: Experience, environment 
and performance. Journal of International Business Studies, 30(2): 269-296.

Luo, Y., \& Tung, R. L. 2007. International expansion of emerging market enterprises: A springboard perspective. Journal of International Business Studies, 38(4): 481-498.

Luo, Y., \& Wang, L. S. 2012. FDI strategies by developing multinational companies: A diagnostic model for home country effects. Global Strategy Journal, 2(3): 244-261.

Luo, Y., Xue, Q., \& Han, B. 2010. How emerging market governments promote outward FDI: Experience from China. Journal of World Business, 45(1): 68-79.

Martin, X., \& Salomon, R. 2003. Tacitness, learning, and international expansion: A study of foreign direct investment in a knowledge-intensive industry. Organization Science, 14(3): 297-311.

Martin, X., Salomon, R., \& Wu, Z. 2010. The institutional determinants of location choice: Agglomeration in the global semiconductor industry. Industrial and Corporate Change, 19(6): 1769-1800.

Martin, X., Swaminathan, A., \& Tihanyi, L. 2007. Modeling international expansion. In D. Ketchen \& D. Bergh (Eds), Research Methodology in Strategy and Management. New York: Elsevier.

Mathews, J. A., \& Zander, I. 2007. The international entrepreneurial dynamics of accelerated internationalization. Journal of International Business Studies, 38(3): 387-403.

McEvily, B., \& Zaheer, A. 1999. Bridging ties: A source of firm heterogeneity in competitive capabilities. Strategic Management Journal, 20(12): 1133-1156.

McGahan, A. M., \& Victer, R. 2010. How much does home country matter to corporate profitability. Journal of International Business Studies, 41(1), 142-165.

Meyer, K. E., Wright, M., \& Pruthi, S. 2009. Managing knowledge in foreign entry strategies: A resource-based analysis. Strategic Management Journal, 30(5): 557-574.

Miller, S., \& Eden, L. 2006. Local density and foreign subsidiary performance. Academy of Management Journal, 49(2): 341-355.

MOFOM. 2009. Statistical bulletin of China's outward foreign direct investment. Beijing: Ministry of Commerce of China.

Nonaka, I. 1994. A dynamic theory of organizational knowledge creation. Organization Science, 5(1): 14-37.

Pedersen, T., \& Shaver, M. 2011. Internationalization revisited: The big step hypothesis. Global Strategy Journal, 1(3/4): 263-274.

Peng, M. 2001. The resource-based view and international business. Journal of Management, 27(6): 803-829.

Rabe-Hesketh, S., \& Skrondal, A. 2008. Multilevel and longitudinal modeling using Stata. StataCorp LP.

Ramamurti, R. 2001. The obsolescing 'bargaining model'? MNC-host developing country relations revisited. Journal of International Business Studies, 32(1): 23-39.

Rangan, S., \& Sengul, M. 2009. The influence of macro structure on the foreign market performance of transnational firms: The value of IGO connections, export dependence, and immigration links. Administrative Science Quarterly, 54(2): 229-267.

Ronen, S., \& Shenkar, O. 1985. Clustering countries on attitudinal dimensions: A review and synthesis. Academy of Management Review, 10(3): 435-454.

Salomon, R., \& Martin, X. 2008. Learning, knowledge transfer, and technology implementation performance. Management Science, 54(7): 1266-1280. 
Schwens, C., \& Kabst, R. 2011. Internationalization of young technology firms: A complementary perspective on antecedents of foreign market familiarity. International Business Review, 20(1): 60-74.

Shamsie, J., Martin, X., \& Miller, D. 2009. In with the old, in with the new: Capabilities, strategies, and performance among the Hollywood studios. Strategic Management Journal, 30(13): 1440-1452.

Shapiro, D., \& Globerman, S. 2003. Foreign investment policies and capital inflows in Canada: A sectoral analysis. Journal of Business Research, 56(10), 779-790.

Sirmon, D. G., Hitt, M. A., \& Ireland, R. D. 2007. Managing firm resources in dynamic environments to create value: Looking inside the black box. Academy of Management Review, 32(1):273-292.

Slangen, A. H. L. \& Beugelsdijk, S. 2010. The impact of institutional hazards on foreign multinational activity: A contingency perspective. Journal of International Business Studies, 41(6): 980-995.

Szulanski, G. 1996. Exploring internal stickiness: Impediments to the transfer of best practices within the firm. Strategic Management Journal, 17(Special Issue): 27-43.

Uhlenbruck, K., Rodriguez, P., Doh, J., \& Eden, L. 2006. The impact of corruption on entry strategy: Evidence from telecommunication projects in emerging economies. Organization Science, 17(3): 402-414.

UNCTAD (2007). Asian foreign direct investment in Africa: Toward a new era of cooperation among developing countries. New York and Geneva: United Nations Publication.

Wang, C., Hong, J., Kafouros, M., \& Boateng, A., 2012. What drives outward FDI of Chinese firms? Testing the explanatory power of three theoretical frameworks. International Business Review, 21(3): 425-438.

Wang, C., Hong, J., Kafouros, M., \& Wright, M., 2012. Exploring the role of government involvement in outward direct investment from emerging economies. Journal of International Business Studies, 43(7): 655-676.

Wright, M., Filatotchev, I., Hoskisson, R. E. \& Peng, M. W. 2005. Strategy research in emerging economies: Challenging the conventional wisdom. Journal of Management Studies, 42(1): 1-33.

Zelner, B. A. 2009. Using simulation to interpret results from logit, probit, and other nonlinear models. Strategic Management Journal, 30(12): 1335-1348. 
Table 1: FDI destinations of sampled firms in the period of 2003-2009

\begin{tabular}{|c|c|c|c|c|c|}
\hline Destination & $\begin{array}{c}\text { Number of } \\
\text { Entry }\end{array}$ & Destination & $\begin{array}{l}\text { Number } \\
\text { of Entry }\end{array}$ & Destination & $\begin{array}{c}\text { Number of } \\
\text { Entry }\end{array}$ \\
\hline Afghanistan & 1 & Hong Kong ${ }^{a}$ & 278 & Portugal & 1 \\
\hline Antigua \& Barbuda ${ }^{\mathrm{b}}$ & 1 & Hungary & 1 & Romania & 2 \\
\hline Argentina & 1 & India & 7 & Russia & 10 \\
\hline Australia & 19 & Indonesia & 7 & South Africa & 3 \\
\hline Bangladesh & 1 & Italy & 10 & Samoa & 1 \\
\hline Belgium & 6 & Japan & 15 & Saudi Arabia & 1 \\
\hline Bermuda $^{\mathrm{a}, \mathrm{b}}$ & 4 & Kazakhstan & 1 & Singapore $^{\mathrm{c}}$ & 26 \\
\hline Br. Virgin Is. ${ }^{a}$ & 58 & Korea Rep. & 8 & Spain & 2 \\
\hline Brazil & 3 & Laos, PDR & 4 & Suriname & 1 \\
\hline Bulgaria & 1 & Liberia & 5 & Sweden & 2 \\
\hline Canada & 10 & Luxembourg & 4 & Switzerland ${ }^{\mathrm{b}}$ & 1 \\
\hline Cayman Is. ${ }^{a}$ & 19 & $\mathrm{Macau}^{\mathrm{a}, \mathrm{b}}$ & 5 & Tadzhikistan $^{\mathrm{b}}$ & 2 \\
\hline Congo & 1 & Malaysia & 5 & Tanzania & 1 \\
\hline Croatia Rep. & 1 & Malta $^{\mathrm{b}}$ & 1 & Thailand & 4 \\
\hline Czech Rep. & 2 & Mexico & 2 & Turkey & 3 \\
\hline Denmark & 1 & Mongolia & 4 & United Arab Emirates & 2 \\
\hline Ecuador & 1 & Netherlands & 25 & United Kingdom & 13 \\
\hline Finland & 2 & Nigeria & 3 & United States & 66 \\
\hline France & 6 & Pakistan & 1 & Venezuela & 1 \\
\hline Germany & 14 & Panama ${ }^{\mathrm{b}}$ & 4 & Vietnam & 8 \\
\hline Ghana & 2 & Philippines & 4 & & \\
\hline Honduras $^{\mathrm{b}}$ & 2 & Poland & 2 & Total & 702 \\
\hline
\end{tabular}

Note: "a" represents countries that are treated as tax heavens in robustness checks; "b" represents countries that were not listed as preferred host countries for Chinese outward FDI in various versions of Guidance Catalogue of Countries and Industries for Overseas Investment. 
Table 2: Summary and correlation statistics

\begin{tabular}{|c|c|c|c|c|c|c|c|c|c|c|c|c|c|}
\hline & & Mean & S.D. & 1 & 2 & 3 & 4 & 5 & 6 & 7 & 8 & 9 & 10 \\
\hline 1 & Entry dummy & 0.04 & 0.20 & & & & & & & & & & \\
\hline 2 & Population & 17.06 & 1.65 & 0.072 & & & & & & & & & \\
\hline 3 & GDP per capita & 8.39 & 1.61 & 0.072 & -0.111 & & & & & & & & \\
\hline 4 & GDP growth rate & 4.61 & 2.61 & -0.030 & 0.079 & -0.605 & & & & & & & \\
\hline 5 & Economic distance & 5.74 & 10.06 & 0.079 & -0.263 & 0.254 & -0.040 & & & & & & \\
\hline 6 & Connectedness distance & 3.17 & 3.11 & 0.070 & -0.226 & 0.615 & -0.340 & 0.310 & & & & & \\
\hline 7 & Political distance & 6.11 & 3.88 & 0.003 & -0.035 & 0.305 & -0.434 & 0.158 & 0.332 & & & & \\
\hline 8 & Administrative distance & 130.59 & 57.45 & -0.022 & -0.179 & 0.273 & -0.117 & -0.022 & 0.315 & 0.100 & & & \\
\hline 9 & Geographic distance & 7.56 & 4.09 & 0.018 & -0.089 & 0.116 & -0.198 & -0.032 & -0.073 & 0.115 & -0.174 & & \\
\hline 10 & Bilateral investment treaty & 0.73 & 0.45 & 0.063 & 0.186 & 0.206 & 0.025 & 0.146 & 0.174 & 0.118 & 0.033 & -0.222 & \\
\hline 11 & Host country institution & 0.44 & 0.95 & 0.068 & -0.192 & 0.863 & -0.610 & 0.306 & 0.646 & 0.278 & 0.251 & -0.071 & 0.099 \\
\hline 12 & Return on assets & 0.04 & 0.08 & 0.004 & -0.003 & 0.003 & -0.033 & 0.005 & -0.006 & -0.001 & -0.002 & 0.001 & -0.016 \\
\hline 13 & Sales & 12.75 & 1.57 & 0.034 & -0.006 & 0.019 & -0.003 & 0.017 & -0.026 & 0.016 & -0.006 & 0.016 & -0.013 \\
\hline 14 & Firm age & 15.63 & 6.02 & -0.012 & -0.001 & 0.015 & 0.023 & 0.010 & -0.018 & 0.013 & -0.003 & 0.013 & 0.009 \\
\hline 15 & Government ownership share & 8.56 & 13.94 & 0.023 & 0.003 & 0.004 & -0.013 & 0.001 & -0.005 & 0.005 & 0.002 & 0.005 & -0.003 \\
\hline 16 & Foreign ownership share & 6.48 & 12.39 & 0.014 & 0.001 & -0.009 & -0.004 & -0.007 & 0.013 & -0.010 & 0.002 & -0.008 & 0.004 \\
\hline 17 & Value of export by the focal firm & 1.67 & 4.47 & 0.077 & 0.108 & 0.089 & -0.036 & 0.020 & 0.043 & -0.001 & 0.001 & -0.021 & 0.053 \\
\hline 18 & Value of export by other firms & 21.25 & 2.95 & 0.081 & 0.418 & 0.448 & -0.325 & 0.133 & 0.234 & 0.120 & 0.057 & -0.014 & 0.162 \\
\hline 19 & Prior entries by the focal firm & 0.06 & 0.41 & 0.390 & 0.030 & 0.073 & -0.036 & 0.068 & 0.067 & -0.021 & -0.022 & 0.004 & 0.028 \\
\hline 20 & Prior entries by other firms & 2.41 & 4.60 & 0.144 & 0.376 & 0.195 & -0.032 & 0.110 & 0.096 & 0.042 & -0.085 & -0.135 & 0.485 \\
\hline 21 & Home country supportive policy & 0.02 & 0.13 & 0.270 & 0.084 & 0.089 & -0.035 & 0.095 & 0.079 & -0.014 & -0.035 & 0.004 & 0.072 \\
\hline
\end{tabular}

\begin{tabular}{|c|c|c|c|c|c|c|c|c|c|c|c|}
\hline & & 11 & 12 & 13 & 14 & 15 & 16 & 17 & 18 & 19 & 20 \\
\hline 12 & Return on assets & 0.004 & & & & & & & & & \\
\hline 13 & Sales & 0.004 & 0.292 & & & & & & & & \\
\hline 14 & Firm age & 0.001 & -0.009 & 0.015 & & & & & & & \\
\hline 15 & Government ownership share & 0.001 & 0.072 & -0.020 & 0.150 & & & & & & \\
\hline 16 & Foreign ownership share & -0.001 & 0.282 & 0.202 & 0.053 & -0.128 & & & & & \\
\hline 17 & Value of export by the focal firm & 0.075 & 0.020 & 0.181 & -0.077 & -0.16 & -0.03 & & & & \\
\hline 18 & Value of export by other firms & 0.403 & 0.019 & 0.054 & 0.016 & 0.013 & -0.026 & 0.123 & & & \\
\hline 19 & Prior entries by the focal firm & 0.079 & 0.034 & 0.104 & 0.054 & 0.021 & 0.069 & 0.071 & 0.073 & & \\
\hline 20 & Prior entries by other firms & 0.127 & 0.005 & 0.080 & 0.061 & 0.014 & -0.041 & 0.075 & 0.362 & 0.131 & \\
\hline 21 & Home country supportive policy & 0.090 & 0.010 & 0.072 & -0.020 & -0.007 & 0.015 & 0.087 & 0.103 & 0.475 & 0.152 \\
\hline
\end{tabular}

Note: Correlations with absolute value equal or larger than 0.029 are significant at 0.05 level. Home country institution is measured with WGI Regulation quality. 
Table 3: Estimation results of fixed effects logit models

\begin{tabular}{|c|c|c|c|c|c|c|}
\hline DV: Entry Dummy & (1) & (2) & (3) & (4) & (5) & (6) \\
\hline \multirow[t]{2}{*}{ Population } & 0.284 & 0.311 & 0.318 & 0.361 & -0.081 & -0.882 \\
\hline & $(0.276)$ & $(0.242)$ & $(0.304)$ & $(0.256)$ & $(0.713)$ & $(1.285)$ \\
\hline \multirow[t]{2}{*}{ GDP per capita } & -0.106 & -0.249 & -0.205 & -0.310 & -0.462 & 3.105 \\
\hline & $(0.342)$ & $(0.391)$ & $(0.422)$ & $(0.444)$ & $(1.197)$ & $(2.845)$ \\
\hline \multirow[t]{2}{*}{ GDP growth rate } & 0.204 & 0.162 & 0.160 & 0.149 & $1.2720^{*}$ & 0.634 \\
\hline & $(0.138)$ & $(0.126)$ & $(0.161)$ & $(0.147)$ & $(0.527)$ & $(0.431)$ \\
\hline \multirow[t]{2}{*}{ Economic distance } & 0.021 & 0.028 & $0.0401+$ & $0.0395 *$ & -0.222 & -0.090 \\
\hline & $(0.020)$ & $(0.018)$ & $(0.021)$ & $(0.020)$ & $(0.169)$ & $(0.147)$ \\
\hline \multirow[t]{2}{*}{ Connectedness distance } & 0.041 & 0.074 & 0.052 & 0.076 & -0.047 & 0.849 \\
\hline & $(0.115)$ & $(0.129)$ & $(0.124)$ & $(0.134)$ & $(0.366)$ & $(0.614)$ \\
\hline \multirow[t]{2}{*}{ Political distance } & 0.096 & 0.058 & 0.109 & 0.081 & 0.087 & 0.302 \\
\hline & $(0.082)$ & $(0.089)$ & $(0.096)$ & $(0.096)$ & $(0.328)$ & $(0.258)$ \\
\hline \multirow[t]{2}{*}{ Administrative distance } & -0.002 & 0.000 & -0.002 & -0.001 & -0.043 & -0.019 \\
\hline & $(0.005)$ & $(0.005)$ & $(0.005)$ & $(0.005)$ & $(0.029)$ & $(0.018)$ \\
\hline \multirow[t]{2}{*}{ Geographic distance } & 0.014 & 0.030 & 0.051 & 0.046 & -0.191 & 0.620 \\
\hline & $(0.074)$ & $(0.073)$ & $(0.078)$ & $(0.079)$ & $(0.296)$ & $(0.449)$ \\
\hline \multirow[t]{2}{*}{ Bilateral investment treaty } & 0.022 & 0.057 & 0.043 & 0.044 & 0.448 & 0.097 \\
\hline & $(0.160)$ & $(0.163)$ & $(0.171)$ & $(0.168)$ & $(0.397)$ & $(0.233)$ \\
\hline \multirow{2}{*}{ Host country institution } & 0.543 & 0.567 & 1.003 & 0.949 & 1.912 & -7.518 \\
\hline & $(0.549)$ & $(0.607)$ & $(0.662)$ & $(0.699)$ & $(3.201)$ & $(4.767)$ \\
\hline \multirow[t]{2}{*}{ Return on assets } & -0.534 & -0.725 & -1.220 & -1.138 & 24.884 & -1.481 \\
\hline & $(2.802)$ & $(2.921)$ & $(2.781)$ & $(2.882)$ & $(15.408)$ & $(3.036)$ \\
\hline \multirow[t]{2}{*}{ Sales } & -0.126 & -0.175 & -0.050 & -0.134 & -0.896 & -0.155 \\
\hline & $(0.162)$ & $(0.169)$ & $(0.170)$ & $(0.174)$ & (1.169) & $(0.179)$ \\
\hline \multirow[t]{2}{*}{ Firm age } & $-0.0781+$ & $-0.0823+$ & $-0.0661+$ & $-0.0763+$ & -0.144 & -0.042 \\
\hline & $(0.041)$ & $(0.045)$ & $(0.038)$ & $(0.045)$ & $(0.115)$ & $(0.045)$ \\
\hline \multirow[t]{2}{*}{ Government ownership share } & $0.0323^{* *}$ & $0.0340^{* *}$ & $0.0336 * *$ & $0.0345^{* *}$ & $0.1622 * *$ & 0.008 \\
\hline & $(0.012)$ & $(0.012)$ & $(0.012)$ & $(0.012)$ & $(0.062)$ & $(0.018)$ \\
\hline \multirow[t]{2}{*}{ Foreign ownership share } & 0.012 & 0.005 & 0.010 & 0.005 & $-0.4485^{* * *}$ & 0.021 \\
\hline & $(0.019)$ & $(0.023)$ & $(0.021)$ & $(0.024)$ & $(0.130)$ & $(0.020)$ \\
\hline \multirow[t]{2}{*}{ Value of export by the focal firm } & $0.0798^{*}$ & $0.0766^{*}$ & $0.0712^{*}$ & $0.0705^{*}$ & $0.5371^{*}$ & 0.028 \\
\hline & $(0.032)$ & $(0.033)$ & $(0.032)$ & $(0.033)$ & $(0.273)$ & $(0.042)$ \\
\hline \multirow[t]{2}{*}{ Value of export by other firms } & 0.053 & 0.015 & 0.020 & 0.003 & 0.223 & 1.019 \\
\hline & $(0.174)$ & $(0.119)$ & $(0.223)$ & $(0.163)$ & $(0.389)$ & $(0.997)$ \\
\hline \multirow[t]{2}{*}{ Prior entries by the focal firm } & 0.738 & $1.8127 * * *$ & $1.5932 * * *$ & $2.1292 * * *$ & $9.6458 * *$ & 1.874 \\
\hline & $(0.594)$ & $(0.515)$ & $(0.310)$ & $(0.411)$ & $(3.046)$ & $(1.699)$ \\
\hline \multirow[t]{2}{*}{ Prior entries by other firms } & 0.002 & 0.003 & 0.002 & 0.002 & $0.0169+$ & -0.001 \\
\hline & $(0.003)$ & $(0.003)$ & $(0.003)$ & $(0.003)$ & $(0.010)$ & $(0.004)$ \\
\hline \multirow[t]{2}{*}{ Home country supportive policy } & $3.4535^{* * * *}$ & $4.2680 * * *$ & $3.1220^{* * *}$ & $3.8839 * * *$ & $16.1128^{* *}$ & $3.5679 * * *$ \\
\hline & $(0.736)$ & $(0.481)$ & $(0.538)$ & $(0.481)$ & $(5.162)$ & $(0.576)$ \\
\hline \multirow[t]{2}{*}{ Lagged DV (Instrument) } & 0.276 & 0.151 & 0.237 & 0.141 & $0.3406+$ & -0.001 \\
\hline & $(0.174)$ & $(0.186)$ & $(0.149)$ & $(0.174)$ & $(0.204)$ & $(0.486)$ \\
\hline $\begin{array}{l}\text { Prior entries by the focal firm * } \\
\text { Home country supportive policy }\end{array}$ & & $-0.1224 * *$ & & $-0.0958^{*}$ & $-0.7954 * *$ & -0.069 \\
\hline & & $(0.041)$ & & $(0.042)$ & $(0.259)$ & $(0.048)$ \\
\hline $\begin{array}{l}\text { Prior entries by the focal firm * } \\
\text { Host country institution }\end{array}$ & & & $-0.5260 * * *$ & $-0.3097^{* *}$ & 1.311 & -0.379 \\
\hline & & & $(0.151)$ & $(0.114)$ & $(0.832)$ & $(0.762)$ \\
\hline R-squared & 0.497 & 0.534 & 0.522 & 0.544 & 0.781 & 0.523 \\
\hline Number of observations & 5068 & 5068 & 5068 & 5068 & 3335 & 1733 \\
\hline
\end{tabular}

Note: Columns (1) - (4) are for the full sample; Column (5) is for the developing country sample; Column (6) is for the developed country sample; + p $<0.10$, * $\mathrm{p}<0.05, * * \mathrm{p}<0.01, * * * \mathrm{p}<0.001$. Home country institution is measured with WGI Regulation quality. 
Figure 1: Graphic presentations of the interaction effects in fixed effects logit models.

$1(a)$

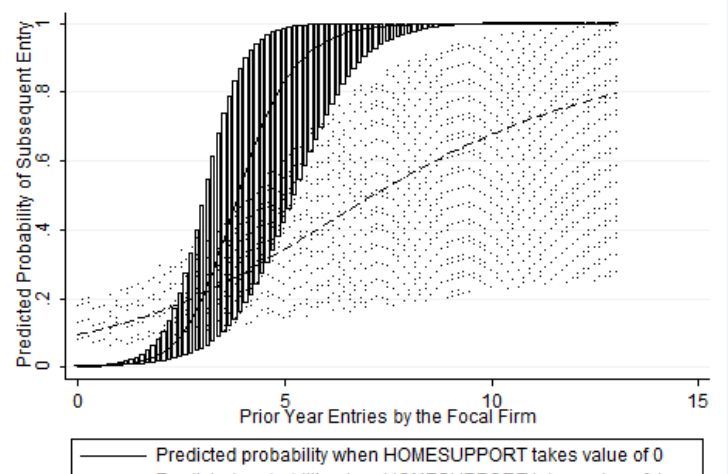

Predicted probability when HOMESUPPORT takes value of 0

$1(c)$

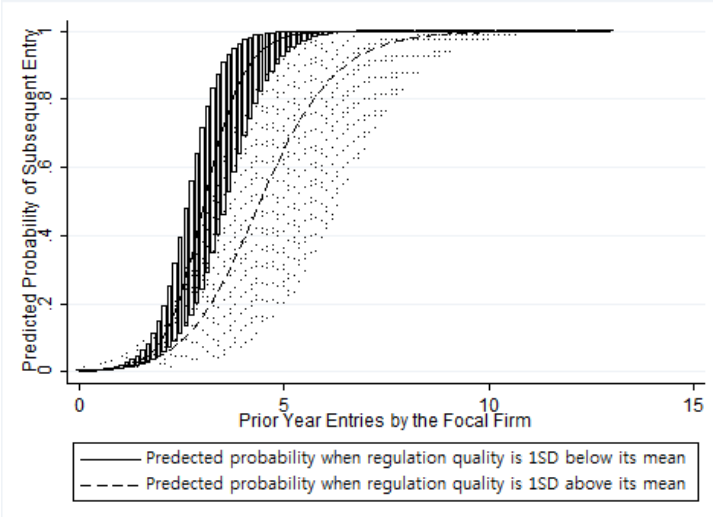

$1(\mathrm{e})$

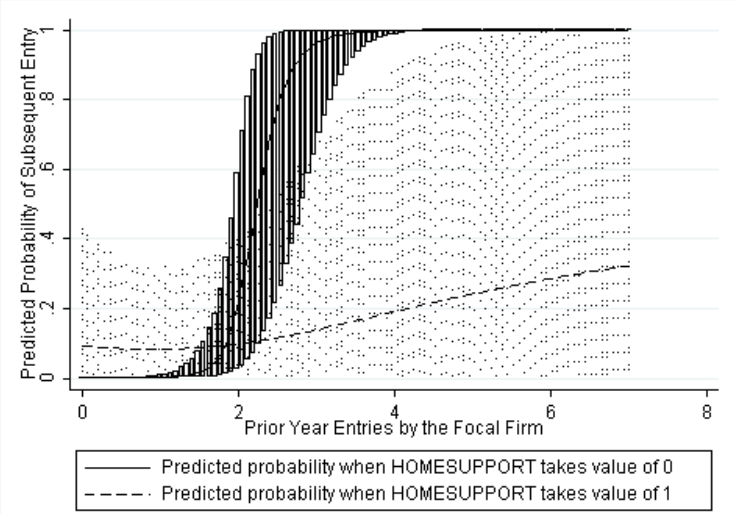

$1(\mathrm{~g})$

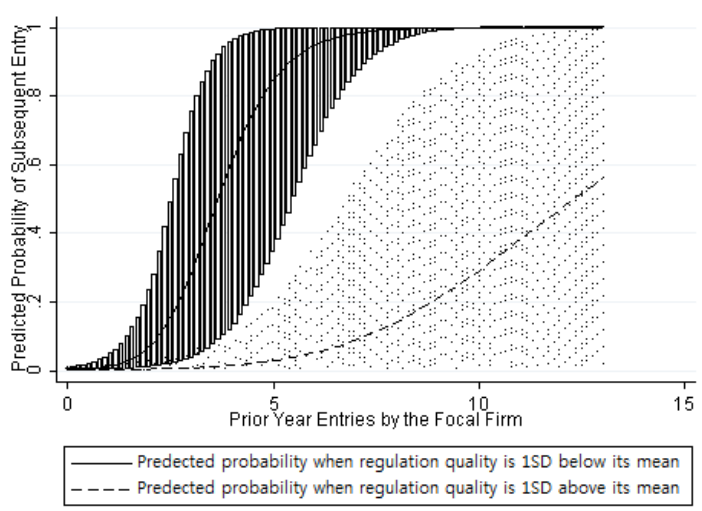

1 (b)

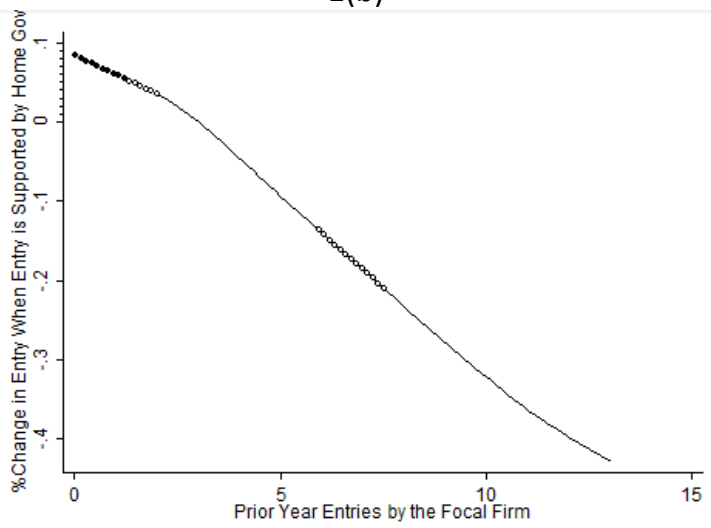

$1(d)$

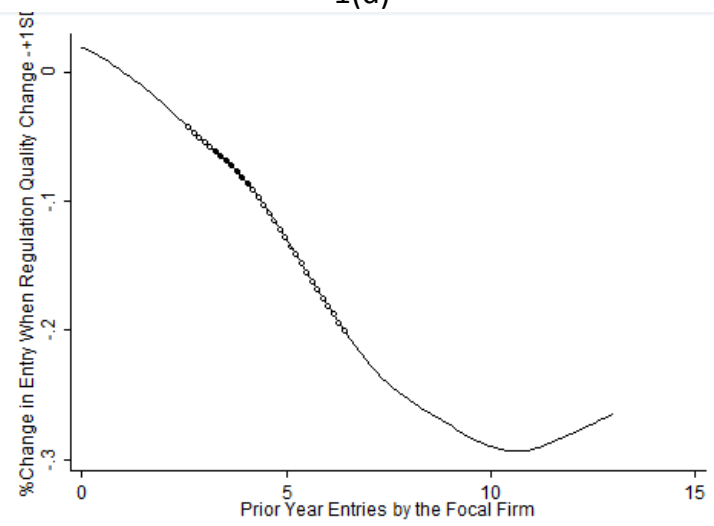

$1(f)$

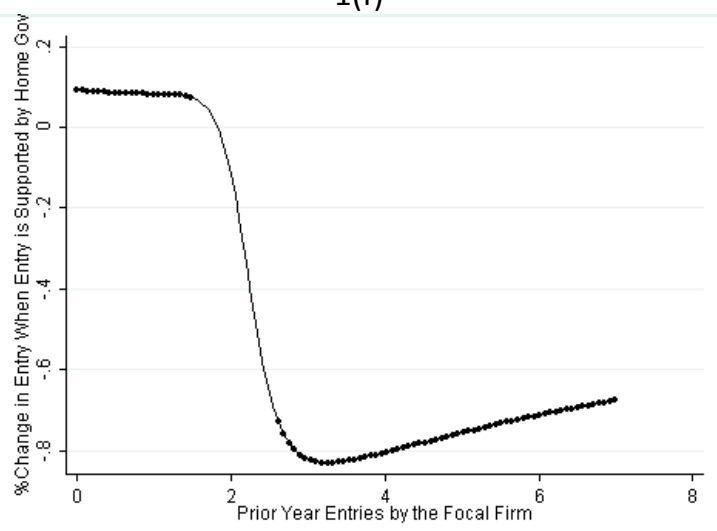

1(h)

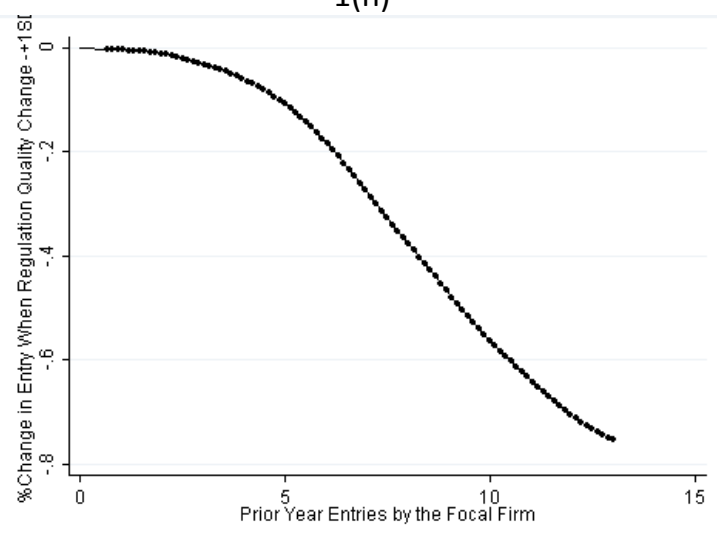


Note: (1a, 1b) represent the interaction effect between Prior entries by the focal firm * Supportive policy in the full sample.

(1c, 1d) represent the interaction effect between Prior entries by the focal firm * Host country institution in the full sample.

(1e, 1f) represent the interaction effect between Prior entries by the focal firm * Supportive policy in the developing countries sample.

$(1 \mathrm{~g}, 1 \mathrm{~h})$ represent the interaction effect between Prior entries by the focal firm * Host country institution in the developed countries sample.

Home country institution is measured with WGI Regulation quality. 